This is an Accepted Manuscript of an article published by Taylor \& Francis in International Journal of Social Research Methodology on 29 January 2020, available online: https://www.tandfonline.com/doi/10.1080/13645579.2020.1721971

\title{
Narrative as Social Action: A Narratological Approach to Story, Discourse and Positioning in Political Storytelling
}

\author{
Samuli Björninen, Mari Hatavara, Maria Mäkelä
}

\begin{abstract}
:
Many sociologists have called for analytical rigor in the study of narrative while maintaining that narrative should be viewed as a form of social action. We argue that the narratological storydiscourse distinction together with positioning theory provides a theoretical basis for such rigor. In narratology, story denotes the events in the world of the narrative, while discourse is the text that communicates them. This distinction helps us see how storytellers take positions on three levels: the story, the communicative (inter)action (discourse), and the level of norms. The third level derives from Michael Bamberg’s positioning theory, which offers a frame of understanding social situatedness of storytelling. Narratological analysis of linguistically discernible voices on the story and discourse levels offers methodological refinements for analysis, finally allowing for a focus on positioning on the third, normative level. The theoretical and methodological arguments are illustrated through analyses of Finnish politicians’ stories.
\end{abstract}

\section{Keywords:}

Narrative analysis, story and discourse, voice, positioning, political storytelling 


\section{Introduction}

In this article we use narratological concepts side by side with narrative positioning theory that stems from narrative studies in the social sciences. We argue that while positioning theory has made valuable contributions to our understanding of storytelling in social interaction, the narratological distinction between story and discourse brings depth to the analysis of contemporary social and political storytelling. More specifically, we aim to show that the distinction between story and discourse enhances our capacity to analyze the means and resources of storytelling: how events are organized, how action is explained and predicted, how motives and intentions are portrayed. Applying this method, our analysis will demonstrate that storytelling not only drives and directs but is social action.

In the article, we analyze stories told by Finnish politicians. The examples are from an online database of interviews with Finnish MPs (conducted and posted in English), and politicians’ public social media profiles. ${ }^{1}$ The database interviews are from 2015 and 2016. Judging from the vantage point of 2019, we can see that storytelling and subsequent political action have aligned in many places. The analysis of contemporary political storytelling exposes some of its ideologically powerful practices that, arguably, contribute to the political climate of 'post-truth': experiential and anecdotal storytelling driving decision-making; the problematic uses of vicarious storytelling; the rhetorical production of representativeness by stereotyping; and the promotion of social action through affective storytelling in social media. In contemporary populist politics, the idea of representativeness is often storified, and parliamentary promoting of interests is replaced by the individuating ethics of encounter. Here narrative positioning plays a crucial role. For example,

\footnotetext{
${ }^{1}$ Tampere University is committed to fulfilling the objectives contained in the "Responsible conduct of research and procedures for handling allegations of misconduct in Finland" guideline issued by the Finnish National Board on Research Integrity, and this research is conducted in line with those ethical guidelines (https://www.tenk.fi/en/tenkguidelines).
} 
tugging at the public's heartstrings with someone else's experience is less of a risk for a politician than sharing one's own. The ethical problems of such instrumentalization of vicarious experience are aptly described by the anthropologist Amy Shuman in her critique of empathy: 'Appropriation can use one person's tragedy to serve as another's inspiration and preserve, rather than subvert, oppressive situations' (Shuman, 2005, p. 5). In this intellectual climate, it is important that narratology uses and develops its tools to better grasp the many uses of narrative in today’s society and politics.

\section{Bringing Narratology and Social Science together}

In narratology, story is understood to consist of events undergone by agents - real or fictional while discourse denotes the presentation, textual or otherwise, that organizes and communicates them (e.g. Chatman, 1978). Simply put, it is a distinction between the things told and the ways of telling them. In textual material, we observe the narrative modes and stylistic organization on the level of discourse. When observing social communicative situations, however, we must see the entire interactive act of storytelling as taking place on the discourse level. In either case, the story level can be seen as an interpretive construct of what happened; the order of events and actions, their causes and motivations, and their effects (e.g. Culler, 1981, pp. 171-172; Walsh, 2007, p. 60).

The discipline of narratology is fundamentally indebted to classic analyses of the relations between the story and discourse levels in literary prose. The most illuminating among them include studies of complex novels like Laurence Sterne’s Tristram Shandy (Shklovsky, 1965) and Marcel Proust’s À la recherche du temps perdu (Genette, 1980). The capacity of these concepts to illuminate such demanding works has made them essential to understanding literary narrative. Ultimately, their successful application in the realm of literature has propelled their adoption as tools for analyzing 
all kinds of narrative (see Abbott, 2007), including those we tell each other in our everyday interactions.

The narratological notion of story and discourse has consequently been brought to psychological theories of storytelling. Keith Oatley employs them in his approach to the study of emotions in empirical storytelling setups (see Oatley, 2002). He traces the terms story and discourse to their familiar origins in the writings of the Russian Formalists, who called them fabula (story) and sjuzhet (discourse) (Tomashevsky, 1965). He uses the term event structure to denote 'the events of the story in the story world.' The term is borrowed from the psychologists Brewer and Lichtenstein, and it is equivalent to the narratological term fabula or story. Discourse structure denotes the text as written, told or performed. Again, this corresponds to the narratological use of sjuzhet or discourse. (Oatley, 2002, pp. 44-45.) Oatley also departs from the narratological tradition by adventurously expanding the basic distinction: in order to delve into the psychology of storytelling, he proposes further two categories, concretization and suggestion structure. The former term is taken from Wolfgang Iser's theory of aesthetic reception that influenced early cognitive accounts of reading (p. 47). With the latter term, he evokes the reading process of individual readers and the interpretations guided more or less overtly by the text (p. 52).

Oatley’s four-part model is highly original, but its psychological extensions are not unknown to literary narratology. The duopoly of story and discourse has been subjected to extensive narratological scrutiny precisely because phenomenological and cognitive approaches to reading have shown that the original distinction cannot account for various effects narrative has for readers (e.g. Culler, 1981; Sternberg, 1978; Pier, 2016). These challenges have produced rich theoretical accounts of how narrative becomes meaningful and how it achieves its effects - in other words, how it becomes engaging and artistically interesting. However, they have not rendered the story- 
discourse model obsolete. This is because it belongs, as Seymour Chatman reminds us, to the level of narrative logic (1988, pp. 13-14). This is why the squarely narratological account of story and discourse might remain the most generally useful contribution to methodology in an interdisciplinary context.

In many instances of storytelling the distinction is at once of crucial importance and perfectly intuitive. For example, a Turkish-born Finnish MP Ozan Yanar, whom we will also discuss later, writes in a recent Facebook status update: 'In many countries, my story would not have been possible. When I moved to Finland at the age of 14, I did not speak a word of Finnish' (emphasis added). This is a translation: the update is written in perfectly fluent Finnish. Yet anyone who reads this post in Finnish will not find any contradiction. It is clear that we intuitively distinguish between two levels: 1) one that involves the event of moving to Finland and the person who is at the time 14 years old and does not know the language, and 2) one that involves the event of telling about it later and the person who does the telling - in fluent Finnish he has learnt in the intervening years. Narratologists like Dorrit Cohn have described in wonderful detail the effects resulting from the temporal and epistemological tension between the narrating self and the experiencing self (1978, pp. 143-153). In an article discussing the uses of narratives in social research, Paul Atkinson and Sara Delamont recognize a similar tension when pointing out the double role of the ethnographer who is 'simultaneously [the] narrator and narrated in his or her textual representations' (Atkinson \& Delamont, 2006, p. 169).

In both social sciences and narratology, the narrative is thus seen as an occasion for agency both on the level of experiencing events and on the level of reflecting and relating them in a narrative form. In both fields, considerations of this dynamic have reached a high degree of sophistication. In an influential sociological theory of agency, George Herbert Mead (1932) theorizes the emergence of 
the 'reflective consciousness,' which operates on three levels: 1) the level of 'contact experience'; 2) the level of 'distance experience'; and, 3) in communicative interaction, in which social meanings and values develop out of the capacity to take on the perspectives of (concrete and generalized) others (pp. 36-37, 83-85). Contact experience denotes the immediacy of experience, while distance experience refers to the human capacity to use ideation and imagery in remembrance and anticipation. Emirbayer and Mische (1998) summarize the dynamic of the two thus:

As actors respond to changing environments, they must continually reconstruct their view of the past in an attempt to understand the causal conditioning of the emergent present, while using this understanding to control and shape their responses in the arising future (pp. 968969).

Recognizing this temporal dynamic is equally crucial to narratology. Indeed, it is one of the main functions of the narratological discourse to reconstruct a view of the past that helps understand the present. This idea becomes more and more central as narratology moves beyond its 'classical' phase and thinks anew the relations of story and discourse (Brooks, 1984; Ricoeur, 1984). In interdisciplinary narrative studies, this idea is also central to narrative psychology that focuses on identity work done through the means of narrative (e.g. Brockmeier \& Harré, 2001). While not narratively oriented as such, even Emirbayer and Mische (1998) include ‘narrative construction’ as one of the central processes in which agency is oriented towards the future, or becomes 'projective' (p. 989). Narratology, having begun as the study of narrative texts, has focused on how the temporal dynamic of 'contact' and 'distance' experience is communicated textually. Its interests, therefore, cut across the levels comprising Mead's model, but its analytic focus is on Mead's third level, the communicative. Narratology has been particularly successful in analyzing how the effects of voice 
and point of view are produced in narrative discourse (Cohn, 1978; Genette, 1980; Lanser, 1981). Indeed, narratology often treats 'voice' as the primary locus of agency on the level of discourse.

However, it is left to the psychologists and sociologists to point out that the temporal human experience itself, so well communicated by narrative means, is social through and through. Even in Mead's early writings sociality is defined as 'the situatedness of actors in multiple temporally evolving relational contexts' (see Emirbayer and Mische, 1998, p. 969). The branch of narrative theory that is perhaps best attuned to the idea of narrative being a locus of social agency is probably narrative hermeneutics. Informed by earlier narrative psychology, narrative hermeneutics sees narrative as a central form of self-interpretation, but also a form of moral and social participation. As Hanna Meretoja writes: ‘we constantly participate, through our actions and inactions, in narrative practices that perpetuate and challenge social structures' (Meretoja, 2018, pp. 11-12). The notion of agency that emerges from these traditions is resonant with narratological thinking while also challenging narratology to think more socially or intersubjectively than usual.

We have seen some of the ways in which social sciences and narratology perceive the act of narration as an occasion for agency. In theorizing emerging from these fields, narrative is seen to afford possibilities for speech and action. In addition, narrative is often portrayed as having several levels of agency. New developments in positioning theory bring together many of the earlier theoretical ideas. As of now, positioning theory has also acknowledged the analytical importance of the narratological story-discourse distinction. Bronwyn Davies and Rom Harré (1990) first introduced the concept of position as a more dynamic alternative to role in social psychology. It was meant to account for the local, reciprocal rights and obligations negotiated in social action: 'a position is a complex cluster of generic personal attributes [...] which impinges on the possibilities of interpersonal, intergroup and even intrapersonal action’ (Harré and van Langenhoven, 1999, p. 
1). From a narratological point of view, the early positioning theory overlooked the distinction between story and discourse (cf. Harré and van Langenhoven, 1999, pp. 16-20). In contrast, Michael Bamberg $(1997,2004)$ shows awareness of the distinction in his more recent model of positioning on three levels: story content (story), storytelling interaction (discourse), and social norms.

Sociologists, such as Atkinson and Delamont, have called for more rigorous approaches to the study of narrative in social sciences while maintaining that 'narrative should be viewed as a form of social action, with its indigenous, socially shared, forms of organization’ (Atkinson \& Delamont, 2006, p. 170). Our claim in this article is that the narratological story-discourse distinction together with positioning theory provides the theoretical basis for such analytical rigor in the sociological study of narratives. Whereas Bamberg's three-level positioning theory offers a frame for understanding social situatedness on both story and discourse levels, the narratological analysis of linguistically discernible voices on the story and discourse levels offers methodological refinements for analysis. The analysis of voices on the story and discourse levels also allows us to focus on positioning on the third, normative level. All three levels of narrative positioning guide social action as they affect the limits and affordances of socially meaningful, desirable and deviant action. Used together, positioning theory and methods of narratological analysis of voice highlight the importance of the distinction between story and discourse in analyzing narrative forms of social action.

\section{From Attributed Voices to Attributed Positions}

Both literary and sociolinguistic types of narratology have identified narrative modes of representing the experience, thoughts and consciousness of another. Both traditions hold the view that these modes are distinctive on the discursive level, where linguistic markers carry traces of two 
subject positions: that of the speaker and that of the represented other (Cohn, 1978; Norrick, 2013).

There is an increased interest in historical, political and social research towards the narrative techniques that enable one to represent the assumed intentions of another: discursive forms that blend two subjects (like free indirect discourse), internal focalization, or the use of mental-state verbs in third-person narrative (Herman, 2011, pp. 7-11). Mari Hatavara and Jarmila Mildorf (2017a; 2017b) have demonstrated that such narrative modes mixing the voices of a teller and another person frequently occur in documentary and interview settings. Whereas personal stories are often used to justify minority opinions in political argumentation (Polletta \& Lee, 2006), the studies so far suggest that the rhetorical purposes and effects of telling stories of vicarious experience are multifarious (Hatavara and Mildorf, 2017b, p. 405). For instance, telling stories about representative characters is an increasingly popular strategy in political rhetoric. ${ }^{2}$ A control over narrative agents and position enables speakers to represent possible scenarios and projected outcomes of political choices in a way that is favorable to their agendas.

Positioning theory (Bamberg, 1997, 2004) helps us understand how the distinction between story and discourse levels, essential in the analysis of narrative texts, can also be made in social interaction, and how this distinction is crucial in understanding normative positioning in political discussion. Positioning theory studies norm-related identity work in situated narrative interaction and in relation to both story content and narrative discourse (Depperman, 2013, p. 2). Narrative positioning refers, first, to positions attributed and taken in the story (level I); second, to positioning in situations where people participate in social interaction (level II); and third, to positioning in relation to identities and normative discourses beyond the particular storytelling situation (level III;

\footnotetext{
${ }^{2}$ For example, Barack Obama and John McCain debated the effect of their respective tax policies for "Joe the Plumber" during the 2008 US presidential election. The debate was based on Obama's encounter with a critical commentator on the campaign trail, but in presidential debates "Joe the Plumber" became a shorthand for the fate of an entire demographic - small business owners in a particular income bracket.
} 
Bamberg, 1997, p. 337; 2004, pp. 136-137). Arnulf Depperman’s (2015, pp. 377-380, passim)

overview of positioning theory further develops the model to better fit both temporal and interactive facets of positioning. Whereas Bamberg's model analyses the levels of story, interaction and identity one by one and leading from one to the other, Depperman's model is fine-tuned to analyzing how the teller on the level of interaction (level II) self-positions themselves in the past story events (level I).

These positioning moves can be identified from the interviews with the use of the speech category approach to narrative voices (Cohn, 1978; Palmer, 2005). Studying the speech categories and their functions enables us to grammatically identify 1) direct or quoted speech/thought in the character's voice, 2) free indirect speech/thought carrying signals of both the narrator's and the character's voices, and 3) indirect speech/thought reported in the narrator's voice, even while the experience represented is often the character's. These categories enable the vital distinction between the speaker and the other character's voice presented within the speaker's speech. Studying different cases of attributing the intentions of another will enable us to identify the discursive means of arguing for political action by evoking vicarious voices alongside the speaker's own.

Our interview examples are from the blog finlandpolitics.org, an English language blog site with various types of posts addressing current politics in Finland. The two texts we analyze are from a series of interviews conducted after the parliamentary election of 2015 to introduce new members of the parliament. Retrospectively, the years between 2015 and 2019 have shown a political trend towards tightening immigration policies, especially when it comes to refugees. Changes have occurred in policies that regulate asylum decision processes, family reunification, and deportation. Our examples from the interviews illustrate these themes before the policy changes took place, and 
they can therefore be seen as efforts to guide prospective action. Without making any claims of verifiable causal relations, we can analyze the kind of narrative means the politicians have used to address these topics that subsequently have been affected by changes in both governmental regulations and public opinion. Our two examples come from different ends of the political spectrum: Ozan Yanar is a member of the Green party advocating both humanitarian-based and other types of immigration rights. Veera Ruoho is a member of the Finns party that promotes restrictions to immigration laws and is especially critical of humanitarian-based immigration.

The first example is taken from an interview of Ozan Yanar on January 20, 2016. He has immigrant background himself, which he mentions in his answer. The interview was conducted and published in English:

Q: You spoke about the refugees. What should be done to faster integrate them in Finland?

\section{A: [--]}

When I look at my background, my life in Finland, it's a big chance that I became what I became. I bumped into some people at critical moments of my life, and talked with them about my future. Should I study politics? Should I study economics? Should I study law? And somebody could have said something, and a sentence got into my mind, and then with that specific point of view, I went to some way, and then I bumped into some other person 3 years later who said something useful. This advice is really important. 
There is also the matter in Finland that, in Finland, people don't want to disturb other people. We have this totally correct society. We are so polite. We don't want to interfere. It does have a positive aspect. But we need also to have people helping others, like social workers, people working with the youngsters, to say to these young kids that there's a lot of opportunities in this country, and 'Yes, you can do it. Believe in yourself', which is not the typical Finnish attitude.

Here we have an example of using a personal story as a means of self-positioning. While in the first paragraph, Yanar positions his past self as a newcomer in Finland, the second paragraph clearly positions him as a current ingroup member of the Finnish culture. This is indicated with the use of the pronoun 'we' to refer to Finns as a group that now includes Yanar himself. In the first paragraph, Yanar positions himself in the interview interaction (level II) as someone who has succeeded in life by retrospectively positioning himself on the story level (level I) as someone who was uncertain of what to do with his life. He uses several discursive voices to produce his story of becoming what he became. First, he offers a few idiomatic questions on the topics he discussed with people he met ('Should I study politics?') on the story level (I). After the questions he switches into the hypothetical mood. This is indicated by the use of the conditional 'could' and also by an inexact or general references to 'somebody' and 'some other person'. This makes Yanar's story an example of not only what happened to him but what could also happen to others.

The second paragraph of the citation is discursively on the level of storytelling interaction (level II) but it also evokes the social norms that Yanar attributes to Finnish culture (level III). The three sentences starting with 'we' express a dual voice, since Yanar is using phrases expressing ideas he presents as typically Finnish. However, at the same time, through simplification and repetition, he 
also takes an ironical stance towards 'us Finns'. In contrast to the typical politeness that prohibits interfering even in positive ways, Yanar presents ‘people helping others’ and their hypothetical speech: 'Yes, you can do it. Believe in yourself' (level I). With the use of this hypothetical direct quotation, Yanar presents an alternative to the cultural norm recognizable to the people of a certain group, in which he includes himself. In this case, positioning on the normative level three (III) is brought to play on level two, the level of interaction (II). Furthermore, the story level (I) with the hypothetical encouraging talk is prospective, not retrospective, and it is therefore a good example of how telling a narrative - using several voices, including hypothetical speech of another person - is used to direct social action and to shape norms. Yanar presents his personal past as an encouraging example for young immigrants from his present position as part of the Finnish people and culture, as someone who can ironically comment on and try to change the behavior of his own group, 'us Finns'.

As a member of the anti-immigration Finns party, Veera Ruoho has rather different stories to tell, and obviously with a different type of message in mind. Ruoho was interviewed on December 9, 2015. Towards the end of her long answer to the question why she became a politician and why she chose the Finns party, she talks about meeting immigrants. This interview, too, was given and published in English:

A: So I chose the Finns party, who was the only one who was quite openly bringing this issue [immigration] up. I also found during the campaign that there were a lot of immigrants who were telling me that, 'Hey, your party is bringing those issues up. It's also, as immigrants, our concern.' For example, some Somali men came to say, 'Yes, 
it’s important to deport those bad people away as soon as possible, because they are spoiling our reputation as well, the ones who are working and behaving well.'

Ruoho offers a frame for her story by remarking on typical comments she would hear while campaigning for election. On the level of interaction (II) she positions herself as a politician who considers the choice of party and makes the decision based on her personal experience of the people’s concerns. The iterative rhetoric of the story gives it a sense of representativeness and generality. Ruoho relates an exemplary meeting with immigrants whose country of origin, Somalia, is given. These little details on the story level (I) are familiar from the tradition of realistic literature, where the details of the world portrayed produce a 'reality effect' (Barthes, 1986). A similar effect is evoked in the mentioning of the country of origin.

Ruoho uses these immigrants as characters in the story (level I) who express opinions she herself holds: in the form of direct speech they voice the view that there are 'bad' and 'good' immigrants, and it is in the interest of both the Finns party and all the good immigrants to deport the 'bad ones'. By making one group of immigrants condemn another group in the form of direct speech, Ruoho positions herself and her interlocutors, the Somali men, on the same side on the story level (I). This is in order to support the more general claim made in the interview interaction (level II) that in advocating tight immigration policies, the Finns party is actually being quite utilitarian. With the help of the immigrants' voice, Ruoho ascribes her cultural and ideological norms (level III) on a portion of the immigrant population. Ruoho wants to change the normative level positioning (III) and turn the public opinion against immigration, and she uses story level positioning (I) - the agreement between herself and 'good' immigrants - to argue the point in the storytelling situation (level II). 
The interviewer next asks a question about the Paris terrorist attack of 2015, a relatively recent event at the time of the interview. In this answer, Ruoho uses negative phrases to express what she did not think or feel:

Q: What is your opinion of the Paris events?

A: To be honest, I wasn't so surprised at all. It was awful. It was so awful, and I feel so sorry for all the French people, and all of the relatives of the victims. I feel so sorry. I was so shocked, but I need, as I said, to be honest: I was not so surprised that these kinds of things are happening. And this is also something that's a very sensitive issue: I am in the Parliament's Foreign Affairs Committee, and early this autumn, we were discussing with some of our Finnish authorities about this issue, and I spoke about the possibility that, among these immigration flows, there could be also some ISIS members. And it was immediately said that, 'No, no, it’s not possible', or 'Of course it's possible, but it's not so likely that it will be happening, because they can use other ways.' But now, since we heard that there are two suspects who have, according to the Greek authorities, used this asylum seekers' channel, that two of those terrorists had this kind of background, it is clear that we must consider the possibility, we can't close our eyes.

Ruoho starts her answer by declaring honesty and continues by telling what she did not feel. The negative expression points to the disnarrated, which covers phrases that relate what did not or does not take place (Prince, 1988, p. 3). The disnarrated emphasizes the discourse level rather than the story level - after all, there is no story content, only negation - and unveils what was expected. By 
telling she was not surprised Ruoho signals a stance in the storytelling situation (level II) towards her action on the story level (I): surprise had been the expected reaction to the events. The declared honesty (level II) of her reaction emphasizes this discrepancy between the commonly expected, which becomes the implicated third level (III) norm, and Ruoho’s reaction (level I).

Ruoho continues with a story of what had happened in the Parliament's Foreign Affairs Committee. This story positions Ruoho (on level I) as the only one with the foresight to expect terrorists to enter Europe posing as asylum seekers. Her savviness is highlighted by the use of hypothetical direct quotations from the less informed committee members. In this story the voices of others are used to oppose Ruoho’s past action on the story level (I). Strong implications for social norms (level III) are evoked on both story and interaction levels. The story level (I) indicates the naivety of Ruoho's colleagues in their own words, while the interaction level (II) suggests that such naivety was not unusual among them. In the last sentence, Ruoho explicitly uses the story as an argument for policy change and preventative action. The Paris incident is presented as proof for her estimate of the present and future threats of immigration.

The interview materials abound with instances of vicarious and personal storytelling. The cases analyzed use several discursive strategies, for example hypothetical direct discourse and the narrative mode of the disnarrated, which are used in pursuing the rhetorical goals of the storytelling situation. Storytelling allows politicians to express, vindicate and object alleged opinions of others in the pursuit of making their own point. Both personal narratives and narratives of vicarious experience can be used to construct positions towards social norms and political decision. Especially in situations where the interviewees seem to aim to influence opinions and norms, several strategies of positioning are used to support the argument. 


\section{Generating Exemplarity on the Discourse Level: Argumentation through Vocal Positioning}

While use of ambiguous and overlapping vocal positions is commonplace in oral contexts such as those analyzed above, written narratives allow for more complexity on the discourse level, partly due to their more evident exposure to literary modes of expression. The example we will turn to next is a much liked and shared Facebook post by Finnish Green Party MP Emma Kari, which tells a moving story about a drug addict who makes a plea to the MP to save the other 'lost boys.' The following analysis foregrounds the importance of the discourse level (II) of positioning in the MP's attempt at a call for prospective social action. Furthermore, also the seeds of possible failure in the attempt of saving the 'lost boys' are located on the discourse level and its repercussions in the social media story economy. The ultimate aim in the analysis is to show how moral exemplarity, used as a narrative means for political argumentation, is crucially dependent on successful positioning on the level of discourse. Similar methods of narratological analysis are applicable in this case as the ones used in the previous examples. In this case, however, also the story logic of social media amplifies and distorts positioning, so much so that the conflicting positionings can be interpreted to counteract the MP's agenda for social and political action.

The public Facebook status update Kari posted on February 20, 2017, shortly before the municipal elections where she stood as a candidate, resulted in approximately 13,000 likes and 1,500 shares. The post, originally in Finnish and presented here as our own translation, comprises of a carefully shaped story of a transformative encounter: 
Today I stood on a stage at a mall in Pori and talked about boys. I talked about how we haven't awoken to the fact that boys are dropping out. Their literacy and grades are declining and the differences are growing. Too many have fallen and many more are just about to. I concluded that we need to take better care of our boys.

When I stepped down from the stage, a man walked to me. He had lost his teeth because of amphetamine, he was glancing furtively and his clothes smelled like dirt. 'You talked about me. I'm one of those lost boys.' I startled. He told me that he was my age, but he looked 20 years older.

He talked fast, almost running out of breath. Maybe he thought that he needed to talk fast because I would soon stop listening. He told me about school which had been fun at first. He talked about realizing how others got it and he wouldn't. He told me about shame and the feeling of being humiliated. Classes at school felt like bullying. Finally he got diagnosed with dyslexia and was sent to the school social worker, but at that point he had already decided that he wasn’t that smart.

Problems kept piling up and nothing worked out. He told me about how he finally lost his grip on life at the vocational school. How he still tried a couple of times but nothing worked out anymore. Finally he just gave up. Now there's no home and no hope for the future. 'My life is over, but you save the rest of those boys,' he said. I promised to do whatever I could. 'That's probably not enough, though,' he said. That hurt.

Walking to the bus, I thought how he had also been someone's little boy. He had a mom who kissed his toes. He had a dad who tickled his tummy. He was loved. He was taken care of. I thought of all those boys who were losing their grip. Maybe if there 
had been someone to catch them in time, their lives would be very different now. It's easier to raise unbroken children than to fix broken adults.

It seems obvious to me that we need to take better care of our boys.

If we focus on the story level (positioning on level I), the post comes across as a description of helplessness at the face of another person's insurmountable ordeals (“"That's probably not enough, though,” he said [...] That hurt'). Kari recounts an experience of a world-disruptive encounter, a story where the felt quality of experience - the qualia (Herman, 2009) - is foregrounded, and all political implications are subordinate to it. Experientiality as the driving force of storytelling is amplified by the intense embodiedness (Fludernik, 1996; Caracciolo, 2014) of the narrated encounter: she 'steps down from the stage' and 'walks to the bus;' especially the man's desperate, breathless, musty, toothless presence is very tangible. As such, the post emblematizes what contemporary, especially cognitive narratology considers to be the prototypical elements of narrative.

According to David Herman, a representation most commonly framed as a narrative by the receiver's cognition is 'a situated account that conveys an ordered temporal and causal sequence of events, a storyworld with particulars, an event that disrupts this storyworld, and the experience of what it is like for a particular individual to live through this disruption' (2009, p. 14). These requirements of experientiality, particularity and world disruption (which in Kari's case takes the form of an epiphany) are key to the aspired 'compellingness' of such politically motivated storytelling. Together these prototypically narrative features generate the dynamics of the transformative encounter, and as such, can be considered to belong to the level I of positioning they primarily shape the agency of storyworld and not discourse participants. From a narratological 
point of view, however, it would be misleading to claim that these prototypical elements belong solely on the level of story, as experientiality, particularity and world disruption are elements both shaping and being shaped in and through narrative discourse.

In this case, as is common in the argumentative use of narratives, the point of the telling is not an individual predicament but its exemplarity: the story is told in order to reach a macro-level conclusion on the necessity of political action against social exclusion. Sociolinguists Anna De Fina and Alexandra Georgakopoulou point out the centrality of both experientiality and exemplarity in their discussion on the use of narrative in argumentative discourse. They note that " experiential” evidence is much more difficult to reject than rational argumentation', thus aligning the rhetorical force of narratives with experientiality. Furthermore, their view of the function of exempla is very similar to how we generally understand exemplum in literary studies, as a narrative genre that 'highlights moral points and underlines [...] moral stances’. (De Fina \& Georgakopoulou, 2012, p. 98.)

As sociolinguists, De Fina and Georgakopoulou are well attuned to the dynamics between story world construction and what they call the 'interactional world' of the telling. Accordingly, they conclude that '[b]ecause argumentative stories are used to back up claims, their focus does not usually rest on reportable events and how they developed, but rather on the significance of those events with respect to argumentative claims’ (ibid. 103). From a narratological perspective we may discern how vocal positioning relates to exemplarity: vicarious schematized speech of individuals and groups - such as 'it was immediately said that, "No, no, it's not possible”' in the previously analyzed interview - is an essential discursive strategy in framing anecdotal, experiential narrative 
evidence as exemplary of a larger social or political issue. In short, such embedded utterances construct exemplary vocal positions.

The social media platforms, by asking 'What's on your mind' and thus teasing out narratives in their prototypical sense (Mäkelä, 2019, pp. 163-164), also prompt the user to foreground their experience of other people's experience. In Kari’s story, this is exemplified by the intense representation of the 'lost boy's' past experiences by translating his alleged speech into vicarious free indirect discourse: 'Problems kept piling up and nothing worked out. [...] Finally he just gave up.' This far, the narration does not violate any conventional expectations, but in a political context where representativeness is a foregrounded concern, it is notable how textual free indirect discourse on someone else's speech has a tendency to internalize that discourse: it is as if the MP actually had access to the 'lost boy's' internal, non-verbalized traumas. At the same time, the internalized discourse is heavily schematized (Fludernik, 1993) by Kari: actual speech to which we will never get access is streamlined into a stereotypical, and as such, representative downhill narrative.

The most problematic part of the narrative, from the narratological, but also the ethical point of view, is the description of the 'lost boy' as a small baby, cuddled by his parents, happily oblivious to his destiny. Here the source of voices and experiences becomes increasingly blurred: did the man relate his story to the MP in all this detail (story level positioning I), and if not, what type of positioning does the discourse point toward? Should we attribute the social action emerging from this story to the narrating self (Cohn, 1978, p. 143), the Emma Kari updating her Facebook as one of her public acts as a politician (level II)? Alternatively, should we think that the political action is induced by the train of thought from the 'lost boy's' happy childhood to 'taking better care of our boys' that occurs to her experiencing self (Cohn, 1978, 145), the Emma Kari of the story, on her 
way to the bus (level I)? While it is possible that the man himself opened up about his happy memories, it is also possible that someone might be fabricating the idyllic image based on her own (middle-class) experiences or a normative cultural frame for what constitutes a 'happy childhood' (normative level positioning III). Our judgment of the rationale and justification of this fabrication can be altered depending on our interpretation of the discursive ambiguities that are foregrounded when Kari’s Facebook post is analyzed with the tools of narratology and positioning theory.

To conclude our analysis, let us draw out the main strategies that contribute to the exemplarity of the story. We do this by focusing on each of the three levels of positioning. At Level I, a distinctive feature of this particular narrative within the genre of 'ethical encounters' between politicians and private citizens is that the 'lost boy' introduces himself as an exemplary narrative agent: 'I'm one of those lost boys.' Moreover, the encounter as recounted follows the Victorian masterplot of the rich girl's epiphany following from an unexpected encounter with a 'deserving poor,' resulting in a radical reevaluation of life goals as the girl decides to dedicate her life to the case of the impoverished. Moreover, the story positions the lost boy as coming from a stable background with loving, caring parents. These storified relations primarily constitute the social and political positioning of actors on the level of the story world.

At level II, the level of discourse, Kari positions herself as a mediator of another's experience on narrative grounds that remain implicit: what exactly did the man tell Kari? To whom should we attribute expressions such as ‘Problems kept piling up and nothing worked out'? Free indirect discourse repositions the 'lost boy' as an exemplum constructed by the MP herself, as a reflection of her own position as a narrative benefactor who wishes to 'give voice' to a marginalized individual. Moreover, particulars on the level of story acquire representativity on the level of 
discourse, first, through Kari's storytelling gesture, and second, through the schematized manner in which they are imagined rather than recounted in Kari’s narrative. They are instrumentalized for a peculiarly narrative induction: 'He had a mom who kissed his toes. He had a dad who tickled his tummy. He was loved. He was taken care of.' The most obvious argument for political action, namely, the statistically salient fact of the hereditariness of social disadvantage and low intergenerational social mobility, is obscured by narrative reasoning. Rather, for the sake of dramatic narrative effect, we are encouraged to imagine that the exemplary 'lost boy' comes from a stable social background and had a happy home. Moreover, the absence of the person whose life story is instrumentalized on levels II and III of narrative positioning further intensifies the discrepancy between the confessional encounter on the story level and the argumentative exemplification on the discourse and normative levels. After all, it is unlikely that the 'lost boy' knows that his story is being shared across social networks as an exemplary and representative narrative.

At level III, the prospect of well-targeted social action boils down to the level of positioning where identity and social norms are negotiated. Yet they are crucially dependent on the dialectics of positioning between story and discourse levels. The political action Kari wishes to induce is that of equal opportunity and social welfare, which acknowledges structural injustices and social inheritance. Yet the narrative dynamics with which she repositions herself as a benefactor encountering an exemplary 'deserving poor' and instrumentalizes the life story of another person may compromise her goal. As a result of the positionings on story and discourse levels, the story's explicit moral, the intended level III positioning ('It's easier to raise unbroken children than to fix broken adults [...] It seems obvious to me that we need to take better care of our boys') comes across as promoting individual ethical agency instead of structural, non-individualising, and political solutions. 


\section{Conclusion}

In our examples, narratives of both personal and vicarious experience are used to invite positioning on the level of story (level I), in the storytelling interaction (discourse, level II), and in relation to social and cultural norms (level III). These positions can be made discernible with the analysis of different voices used in the discourse. Besides their own voice, the narrators incorporate voices of their former selves and other people. This occurs mostly via direct discourse and free indirect discourse. The narrators often employ hypothetical voices of others on the story level to argue for their own points on the discourse level. Instead of pursuing their claims openly and trying to argue for them with facts, politicians offer stories as tools for making sense of human action in situated social realities. If we accept the argument that narrative is a strategy for explaining the unexpected and structuring experienced reality (cf. Bruner, 1990), we could now make the further claim that narratives are powerful tools for political advocacy and promoting social action. In our 'post-truth' era, thoroughly informed by the logic of social media, opinion and action are increasingly influenced by storytelling and narrative strategies. Emotionally engaging, often unverifiable stories are used to exemplify, explain, and predict the intentions of others in order to guide prospective action. In our examples, other voices are used either as like-minded support to the speaker's views and actions, or as ironical examples of misconception to portray the speaker as someone who knows better. Since the logic of storytelling is sequential and causal, these narratives of personal and vicarious experience strongly promote future action towards the political causes advanced by the speaker.

Whereas the narratological analysis of voices enables making the distinction between positioning on story and discourse levels, the three-level model of narrative positioning helps situate these positions in social reality and in relation to normative expectations that guide social action. The 
distinction between story and discourse enables the analysis of voices and positions in the storytelling situation and in the story told, and shows how storytelling can be fashioned towards particular rhetorical purposes. The distinction also enables the analysis of discrepancies between the story level and storytelling level in relation to normative positions. The narrator on the discourse level tells the story to make a point, but the point does not originate in the character(s) of the narrated story but belongs to the narrator who controls the storytelling interaction. Stories help politicians to position themselves and others in implicit but influential ways. The use of vicarious experience for rhetorical purposes makes clear the ethical problems of political storytelling: the use of other people's stories as schematized exempla to argue for one's point distorts the agency of the voices presented on the story level. The vicarious voices become carriers of meanings the storyteller uses for her rhetorical purposes on the interaction level, and their use aims to affect the normative level.

Finally, a word about the possible significance of the kind of research that produces detailed textual analyses of interview and social media materials: why would this matter to research on social action? Our suggestion is that teaming up with narratologists may help social scientists analyze and interpret the layers of intentions in their materials, and to gain a more encompassing picture of the dynamics of narratives. Conversely, when narratologists with a background in literary studies wish to turn their attention to non-literary narratives they encounter in multidisciplinary settings, their research can crucially benefit from the expertise that social scientists have on empirical work with informants, data handling, research ethics and qualitative methods. 


\section{References}

Abbott, H. P. (2007). Story, plot, and narration. In D. Herman (Ed.), The Cambridge companion to narrative (39-51). Cambridge, UK: Cambridge University Press.

Atkinson, P., \& Delamont, S. (2006). Rescuing narrative from qualitative research. Narrative Inquiry, 16(1), 164-172.

Bamberg, M. (1997). Positioning between structure and performance. Journal of Narrative and Life History, 7(1-4), 335-42.

Bamberg, M. (2004). Positioning with Davie Hogan. Stories, tellings, and identities. In C. Daiute \& C. Lightfoot. (Eds.), Narrative analysis. Studying the development of individuals in society (pp. 135-57). Thousand Oaks, CA: Sage.

Barthes, R. (1986). The rustle of language. (R. Howard. Berkeley, Trans.). University of California Press.

Brockmeier, J., \& Harré, R. (2001). Narrative: Problems and promises of an alternative paradigm. In J. Brockmeier \& D. Carbaugh (Eds.), Studies in Narrative: Vol 1 (pp. 39-58). Amsterdam: John Benjamins Publishing Company.

Brooks, P. (1984). Reading for the plot: Design and intention in narrative. Cambridge, MA: Harvard University Press.

Bruner, J. (1990). Acts of meaning. Cambridge, MA: Harvard University Press.

Caracciolo, M. (2014). The experientiality of narrative: An enactivist approach. Berlin: De Gruyter.

Chatman, S. (1978). Story and discourse: Narrative structure in fiction and film. Ithaca, NY:

Cornell University Press.

Chatman, S. (1988). On deconstructing narratology. Style, 22(1), 9-17. 
Cohn, D. (1978). Transparent minds. Princeton, NJ: Princeton University Press.

Culler, J. (1981). The pursuit of signs: Semiotics, literature, deconstruction. Ithaca, NY: Cornell University Press.

Davies, B., \& Harré, R. (1990). Positioning: The discursive production of selves. Journal for the Theory of Social Behaviour, 20(1), 43-63.

De Fina, A., \& Georgakopoulou, A. (2012). Analyzing narrative. Discourse and sociolinguistic perspectives. Cambridge, UK: Cambridge University Press.

Depperman, A. (2013). Positioning in narrative interaction. Narrative Inquiry, 23(1), 1-15.

Depperman, A. (2015). Positioning. In A. de Fina \& A. Georgakopoulou (Eds.), The handbook of narrative analyses (pp. 369-387). Oxford: Wiley Blackwell.

Emirbayer, M., \& Mische, A. (1998). What is agency? American Journal of Sociology, 103(4), 962-1023.

Fludernik, M. (1993). The fictions of language and the languages of fiction: The linguistic representation of speech and consciousness. London and New York, NY: Routledge.

Fludernik, M. (1996). Towards a 'natural' narratology. London and New York, NY: Routledge.

Genette, G. (1980). Narrative discourse: An essay in method. Translated by Jane E. Lewin. Ithaca, NY: Cornell University Press.

Harré, R., \& van Langenhove, L. (1999). The dynamics of social episodes. In R. Harré \& L. van Langenhove (Eds.), Positioning theory: Moral contexts of intentional action (1-13). Oxford: Blackwell.

Hatavara, M., \& Mildorf, J. (2017a). Hybrid fictionality and vicarious narrative experience. Narrative, 25(1), 65-82. 
Hatavara, M., \& Mildorf, J. (2017b). Fictionality, narrative modes, and vicarious storytelling. Style, 51(3), 391-408.

Herman, D. (2009). Basic elements of narrative. Oxford and Malden, MA: Wiley Blackwell.

Lanser, S. S. (1981). The narrative act. Princeton, NJ: Princeton University Press.

Mäkelä, M. (2019). Literary Facebook narratology: Experientiality, simultaneity, tellability. Partial Answers, 17(1), 159-182.

Mead, G. H., \& Murphy, E. (1932). The philosophy of the present. Chicago, IL: Open Court Publishing Co.

Meretoja, H. (2018). The ethics of storytelling: Narrative hermeneutics, history, and the possible. New York, NY: Oxford University Press.

Oatley, K. (2002). Emotions and the story worlds of fiction. In M. C. Green, J. J. Strange \& T. C. Brock. (Eds.), Narrative impact: Social and cognitive foundations (pp. 38-57). London: Lawrence Erlbaum Associates.

Palmer, A. (2005). Thought and consciousness representation (literature). In D. Herman, M. Jahn \& M. Ryan (Eds.), Routledge encyclopedia of narrative theory (pp. 602-606). London and New York, NY: Routledge.

Pier, J. (2016). The configuration of narrative sequences. In R. Baroni \& F. Revaz (Eds.), Narrative sequence in contemporary narratology (pp. 20-36). Columbus, OH: The Ohio State University Press.

Polletta, F., \& Lee, J. (2006). Is telling stories good for democracy? Rhetoric in public deliberation after 9/11. American Sociological Review, 71(5), 699-723.

Prince, G. (1988). The disnarrated. Style, 22(1), 1-8. 
Ricoeur, P. (1984). Time and narrative. Vol. 1. (K. McLaughlin \& D. Pellauer, Trans.). Chicago,

IL: University of Chicago Press.

Shklovsky, V. (1965). Sterne’s Tristram Shandy: Stylistic commentary. In L. T. Lemon \& M. J. Reis (Eds.), Russian formalist criticism: Four essays (pp. 25-60). Lincoln, NE: University of Nebraska Press.

Shuman, A. (2005). Other people's stories: Entitlement claims and the critique of empathy. Urbana, IL: University of Illinois Press.

Sternberg, M. (1978). Expositional modes and temporal ordering in fiction. Baltimore, MD: Johns Hopkins University Press.

Tomashevsky, B. (1965). Thematics. In L. T. Lemon \& M. J. Reis (Eds.), Russian formalist criticism: Four essays (pp. 61-95). Lincoln, NE: University of Nebraska Press.

Walsh, R. (2007). The rhetoric of fictionality: Narrative theory and the idea of fiction. Columbus, OH: The Ohio State University Press.

This is the accepted manuscript version of the article published in International Journal of Social Research Methodology https://doi.org/10.1080/13645579.2020.1721971. Copyright: Taylor and Francis Online. Please contact publisher for permission to re-use the material in any form. For citations, please refer to the published version 